\title{
INVESTIGATION OF THERMAL PROPERTIES OF NATURALLY SEASONED DRY Macaranga barteri TIMBER BOARD
}

\author{
S. E. Etuk, E. E. Eno and L. E. Akpabio \\ Department of Physics, University of Uyo, Nigeria, Email: sunetuk2002@yahoo.com
}

\begin{abstract}
Steady-state thermal conductivity measurements of naturally seasoned African thorn tree (Macaranga barteri) timer boards were carried out. Other thermal and physical properties such as specific heat capacity, thermal resistivity, density, thermal absorptivity and diffusivity as well as percentage of dead air space (v/v) were also determined for the wood samples. The results showed that Macaranga barteri timber board, naturally seasoned to dryness has thermal conductivity of $0.0692 \pm 0.0061 \mathrm{Wm}^{-1} \mathrm{~K}^{-1}$ mean specific heat capacity value of $1898.389 \pm 19.831 \mathrm{~J} \mathrm{Kg}-$ ${ }^{1} \mathrm{~K}^{-1}$, thermal absorptivity and diffusivity values of $18.4226 \pm 1.3332 \mathrm{~m}^{-1}$ and $(1.0731 \pm 0.1560) \times 10^{-7} \mathrm{~m}^{2} \mathrm{~s}^{-1}$ respectively. It has a bulk density of $339.82 \pm 15.49 \mathrm{Kgm}^{-3}$ and particle density of $413.53 \pm 28.18$ with $17.82 \pm 1.81 \%$ as mean percentage volume of dead air space. These results are comparable with those of the conventional insulators, hence the wood material is a potential thermal insulator for building design
\end{abstract}

Keywords: Macaranga bateri, bulk density, naturally seasoning, timber boards, thermal

properties

\section{INTRODUCTION}

Timber, from the earliest times has furnished mankind with necessities of existence and with comfort and conveniences, particularly in housing, yet it has not always been used efficiently (USA Forest Products Laboratory, 1974). Ajibola and Falade (1990) also acknowledged the contribution of timber as one of the readily and flexible local building materials in Nigeria, observing that few timber species are becoming expensive due to extensive exploitation of their reserves. Ajibola and Onabanjo (1995) reported that though there seems to be an abundance of wood resources, structurally suitable for building as well as possessing potential for energy conservation, only a few attempt have been made to establish their suitability.

It is in consideration of the above that this research, which involves, in the main, measurement of heat flow in African thorn tree (Macaranga barteri) timber is embarked upon. (Macaranga barteri) is one of the trees that are found in the tropical rain forest. It grows in the wild in Nigeria, as well as many parts of the world. It is characterized by branched thorny trunk with small leaves. The thorns are usually very sharp at the tip and longer in size than that of kapok tree Ceiba pentandra.

The leaf is used for feeding of goats while, the trunk is used for fire-wood. It can grow to a diameter of about $0.5 \mathrm{~m}$ and height of $9 \mathrm{~m}$. Slender sized Macaranga barteri is sometime used for skeletal construction of indigenous African mud building (Etukudo, 2000).

There is no denial that some researchers have worked on the physical and thermal properties of some plant or timber species. Such include the work of Ajibola and 
Onabanjo (1995), Akpabio et al (2001), Etuk et al (2002), Etuk et al (2003), Etuk and Akpabio (2004), Etuk et al (2005), Bolza and Keating (1972), Ekpa et al. (2000) and Van Straaten (1967). However, no study has been reported on the thermal properties of Macaranga barteri timber board as a thermal insulating element.

This work therefore outlines the properties to be investigated to include; thermal conductivity, resistivity, diffusivity and absorptivity. Other properties are; specific heat capacity, bulk and particle density, percentage volume of air space and, of course, the porosity.

\section{MATERIAL AND METHOD \\ Preparation of sample}

Boards of Macaranga barteri timber were obtained from three different locations of Akamkpa in Cross River State, Okobo and Afaha Ibesikpo both in Akwa Ibom State, Nigeria. The boards, which had their sample specimens weighed for wet mass, were kept in a dry environment exposing them to natural drying. The weighed sample specimens were subjected to periodical weighing until constant mass were obtained (dry mass). The moisture content of the wood samples was obtained using the relationship.

\section{Percentage Moisture content of fresh sample $=\frac{\text { Wet mass } \mathbf{I} \text { Dry mass }}{\text { wet mass }}$}

The moisture content of all the wet/fresh samples were calculated and the mean value obtained to be $45.27 \%$.

The dry boards were then shaped into required sample sizes of $6.02 \pm 0.05 \mathrm{~cm}$ and $1.10 \pm 0.05 \mathrm{~cm}$ thick.

Thermal conductivity, which is the quantity of heat flowing in a steady state through a material of unit thickness when a unit difference of temperature is established between its faces as expressed by many authors including Ajibola and Onabanjo (1995), Etuk et al (2003b), Etuk and Akpabio (2004) thus

$Q=K A\left(T_{h}-T_{c}\right) / X$

Where $\mathrm{T}_{\mathrm{h}}=$ Temperature of the hot face $(\mathrm{k})$

$\mathrm{T}_{\mathrm{C}}=$ Temperature of the cold face $(\mathrm{k})$

$\mathrm{X}=$ The coordinate through the thickness of the material sample (m)

$\mathrm{K}=$ thermal conductivity of the material $\left(\mathrm{Wm}^{-1} \mathrm{~K}^{-1}\right)$

$\mathrm{A}=$ Unit Area $\left(\mathrm{M}^{2}\right)$

$\mathrm{Q}=$ Heat flow.

The heat flow was determined from fifteen sample specimens from the three locations earlier mentioned, using steady stead method (Etuk and Akpabio 2004). Equation (1) was employed for the calculation. Dry sample was used to avoid the problem of redistribution of water under the influence of temperature gradient (J ackson and Taylor, 1965).

A well-lagged calorimeter with sensing element was used for the determination of specific heat capacity $\mathrm{C}$ of the sample specimen using modified cooling correction method to avoid heat loss through process of radiation (Ekpe and Akpabio, 1994). Density $\rho$ was also measured for the samples using weighing and displacement 
method (Ekpe and Akpabio, 1994). Percentage volume of dead air space, was determined by the process of Archimedes' Principle, which also enhanced the determination of particle density $\rho_{p}$ separate from bulk density $\rho_{B}$.

Thermal diffusivity $\lambda=k / \rho_{B} c$ and absorptivity $\alpha=(\omega / 2 \lambda)_{1 / 2}$ were calculated for each of the fifteen samples. Thermal resistivity, a reciprocal of thermal conductivity was also calculated, where $\omega$ is the angular frequency of the solar energy radiation.

According to Walton (1970), properly seasoned timber always contains a small amount of moisture, usually in the range of $8-16 \%$ of the oven dry weight of the wood material. This moisture content is rarely static, but tends to fluctuate with seasonal changes due to humid weather. In order to obtain the moisture content of the seasoned dry sample that was actually experimented on, the sample specimens already seasoned to dryness, to a constant mass, were subjected to method put forward by Walton. In the oven dry method a sample piece was first weighed, then dried in an electric oven at about $60^{\circ} \mathrm{C}$ for 48 hours and then transferred to a desicator having completely charged silica gel; and then the sample was allowed to be there for 24 hours in order to remove all the moisture. A sensitive weighing balance (Adventure Ohaus Model No AR3130, S/ No 8727347088) was used to measure the mass of the samples immediately the samples were removed from the desicator. The new mass was recorded for the code given to each sample. Moisture content of the oven dry weight of the wood materials was calculated using the expression given by Walton (1970) thus:

Percentage Moisture content after seasoning $=\frac{\text { Mass after seasoning } 1 \text { Oven dried mass }}{\text { Oven dried mass }} \times \frac{100}{1}$

The values were calculated and recorded accordingly. The mean moisture content in the seasoned wood samples is shown to be $7.59 \%$, about the minimum value given by Walton as earlier indicated in this work.

\section{RESULT AND DISCUSSION}

A typical sample result obtained from the experiments and calculations is represented in Table 1 . The result indicates a low thermal conductivity value of $0.0692 \pm 0.0061 \mathrm{Wm}^{-1} \mathrm{~K}^{-1}$ for the dry timber board. This may be attributed to the volume for dead air in the space in the cell cavity, which equally accounts for low bulk density with a high thermal resistivity making the board a good thermal insulating material. This is supported by the report of Walton (1970) that some species of low density wood have a greater amount of dead air space in the cell cavities, which gives the timber better insulating and acoustic properties than heavier timbers. Another report by United States of America (USA) Forest Laboratory (1974) has it that thermal conductivity of wood is affected by density, moisture content, extractive content, grain direction and structural irregularities such as checks and knots.

More so, closely packed particles materials have high bulk densities and corresponding low pore spaces, thereby enhancing the thermal contact between the solid particles. This lowers the amount of the low conductivity air, thus increasing the overall thermal conductivity of the material. However, from the table, result shows mean percentage volume of dead air space to be $(17.82 \pm 1.81) \%$, resulting in 
low bulk density as compared to particle density, with high percentage low conductivity air, thus reducing overall thermal conductivity of the sample board. Thermal conductivity plays a key role in heat transfer process (Garcia - Pay and Izquierdo_Gil, 2004).

The results in Table 1 also show low level of thermal diffusivity for the material. Thermal conductivity is a function of thermal diffusivity and the two properties are directly proportional to each other. Other factors that influence thermal diffusivity are specific heat capacity and density, which are both inversely proportional to diffusivity. Low thermal conductivity with high specific heat capacity lowers the amount of diffusivity, which is the case with the material under investigation, hence favouring it as a good thermal insulator. Thermal absorptivity value for the research sample is seen to be high. This is due to the fact that this property relates inversely proportional to thermal diffusivity, such as, the lower the thermal diffusivity, the higher the absorptivity, and since thermal diffusivity for our sample is low, it is plausible for the absorptivity value to be high and this also supports the property of the samples as thermal insulating in nature.

Thermal conductivity and density values obtained for African thorn tree timber seasoned to dryness is comparable with those of Pine Fiberboard with Density of 256 $\mathrm{kgm}^{-3}$ and thermal conductivity value of $0.052 \mathrm{Wm}^{-1} \mathrm{~K}^{-1}$ and thermal resistivity value of $19.231 \mathrm{~W}^{-1} \mathrm{mK}$ (Twidell and Weir, 1990). The specific heat capacity value so obtained is closed to that of wood fiberboard having $1428 \mathrm{~J} \mathrm{~kg}^{-1} \mathrm{~K}$ (Diamant, 1986). The values are closed to the range of values obtained by Etuk et al (2003) for Raphia hookeri trunk, which has density value of $278.667 \pm 2.054 \mathrm{Kgm}^{-3}$, thermal conductivity of $0.053 \pm 0.002 \mathrm{Wm}^{-1} \mathrm{~K}^{-1}$, and Specific heat capacity $2456.33 \pm 5.73 \mathrm{~J} \mathrm{Kg}^{-1} \mathrm{~K}^{-1}$, Thermal resistivity value $19.007 \pm 0.132 \mathrm{~W}^{-1} \mathrm{mK}$.

In summary, thermal properties of dry African thorn tree (Macaranga barteri) timber as shown by our result, when compared with thermal properties of other known wood-based thermal insulators as tabulated by Ajibola and Onabanjo (1995) and Asbestos cement sheet with thermal conductivity value of $0.319 \mathrm{Wm}^{-1} \mathrm{~K}^{-1}$ as given by Twidell and Weir (1990), is therefore a better thermal insulator.

\section{CONCLUSION}

Based on the experimental result and its comparison with values of thermal properties of already known thermal insulators, it suffices to conclude that dry African thorn tree timber is a good thermal insulator and can be used as insulating board for self cooled building in areas of severe or harsh climatic condition. More so, the wood species is locally and abundantly available in Nigeria.

\section{REFERENCES}

Abedinov N., Grabiec P., Gotszaik, I. Tz., Voigt, J. and Rangelow, I. W. (2001): Micromachined Piexorestive Cantilever Array with integrated resistive Microheater for Calorimetry and Mass Detection J. of Vac. Sci. and Tech. A. A., 19 (6): 2884.

Ajibola, K. and Falade, F. (1990): Determination of Some Structural Properties of African Palm Timber (Elais quineensis). Ife J . Technol, 1(2): 24-29. 
Ajibola, K. and Onabanjo, B. O. (1995): Investigation of Coco nucifera as a potential insulator for buildings. Ren. Energy 6 (1): 81 - 84

Akpabio L.E., Ekpe S.D Etuk S.E and Essien K.E (2001): Thermal Properties of Oil and Raffia Palm Fibres. Global J . of pure and Appl. Sci. 7 (3): 575 - 578.

Bolza, E. and Keating W. G (1972): African Timbers - the properties use and characteristics of 700 species, Melbourne Australia: Division of Building Research Common Wealth Scientific and Industrial Research organization.

Cocorullo G., Della Corte F.G and Rendina I. (1999): Temperature Dependence of the thermo-optic Coefficient in Crystalline Silicon between Room Temperature and 550k at the Wavelength of 1523nm App. Phys. Let. 74 (22):3338.

Ekpe S.D (2005): Study of Energy flux in a Magnetron sputter Deposition system. A Ph. Thesis. Electrical/ Computer Engineering, University of Alberta, Canada.

Ekpe S. D and Akpabio G. T. (1994): Comparison of Thermal properties of soil samples for a passively cooled building design. Turk J . of Phys. 18:117-122.

Ekpe S. D and Dew S. K (2002): Investigation of thermal flux to the substrate during sputter Deposition of Aluminum. J. Vac. Sci. technol. A 20 (6): 1877 1885.

Ekpe S.D. Akpabio L.E. Eno E.E. and Etuk S.E., (2000): Gamma Radiation Determination of Transverse Absorption Coefficient of Wood. Global J of Pure and App. Sci. 6 (1): 157 - 160.

Etuk S.E., Akpabio, I.O., Udo E.M. (2003): Comparison of the thermal properties of clay samples as potential walling material for naturally cooled building design J . of Envron. Sci. 15 (1) 65:68

Etuk S. E. and Akpabio L.E (2004): Investigation of Ceiba pentandra Cotton as a potential thermal insulator. J ORMAR 1(1): 4-10

Etuk S.E., Akpabio L.E, Akpabio K.E (2005): Determination of Thermal Properties of Cocos nuclcefera Trunk for predicting Temperature variation with it thickness. Arabian J . Sci. and Engineering 30 (13): 121 - 126.

Etuk S.E., Akpabio L.E, Akpabio K.E (2003b): Investigation of Raphia hookeri trunk as a potential ceiling material for passively cooled building design. Ghana J . Sci. 43:3-7

Etuk S.E., Akpabio L.E, Akpabio K.E (2002): Investigation of Musanga cecropiodes heartwood as a thermal insulator for refrigerators, coolers and food flask, Ghana J. of Sci. 42:71-76.

Etukudo I. (2000): Forests: Our Divine treasure. Dorand, Uyo p. 18.

Garcia Payo and Izquierdo - Gill M. C (2004): Thermal resistance Technique for measuring the thermal conductivity of Thin microspores membranes $\mathrm{J}$. Phys. D: Appl. Phys 37: 3008 - 3016

Jackson R.D. and Taylor S.A (1965): Heat Transfer, method of soil analysis. Agronomy Monograph 9. (1): 349-360.

Kersten H. Steffen H., Vender D. and Wagner H. E. (1995): On the Ion Energy Transfer to the Substrate during Titanium Deposition in a Hollow Cathode Arc. Discharge, Vac 46 (3): 305.

Kimball B.A and Jackson R. D (1976): Soil heat flux determination: temperature gradient method with computed thermal conductivities. Soil Sci. Soc. Am. J ., 40; 26-28.

Lysenko V., Perichon S., Remaki B, Barbier D. and Champagnon B. (1999): Thermal Conductivity of thick Meso - porus Silicon Layers by MicroRaman Scattering. J . of App. Sci. 86 (12): 6841. 
McCammoon, D., Han S. I, Lesser A. Sanders E., Kelley R. L., Moseley S., H., Porter F.S., Stahle S.K and Szymkawiak A.E (1999): Highresolution Calorimetry Limitations of Doped Semi-Conductor Thermometers. Nuclear Instruments and Methods in Physics Research A. (436): 205.

Moon I.K., J ung D.H., Lee K.B, and Jeong Y.H (2000): Peltier Microcalorimeter. App. Phy Let. 76 (17) 2451.

Nishini H., Yang W., Dohnalek Z., Ukraintsev V.A., Choyke W.J and Yates J .T J r. (1997): Silicon Crystal heating and Thermocouple Mounting Using Pulsed Photo-thermal radiometry and Silver Hallide Infra red Optical Fibres Appl. Phy Lett. 70 (12): 150.

Ochsner TE., Horton R. and Ren T. (2001): A new perspective on Soil thermal properties. Soil Sci. Soc. Am. J . 65:1641-1647

Osim E.E., Udo E. M., Etta K.M (1988): Lung function in Nigerian Cement Factory Workers. A Paper presented at the 17th Annual Scientific Conference of the West African Society for Pharmacology WASP.

Steffen H., Kersten H., Wulff H. (1994): Investigation of the Energy Transfer to the substrate during the Titanium Deposition in a Hollow Cathode Arc. J . of Vac. Sc. And Tech., A. 12 (5): 2781.

Twidell J . and Weir T. (1990): Renewable Energy Resources E. and F. N. Spon, London p. 418.

United States Forestry Products Laboratory (1974): Wood Handbook: wood as an engineering material, US Government Printing office, Washington, $p$ iii

Van Straaten, J . F (1967): The Thermal Performance Characteristic of certain wall construction in warm climates, Melbourne, Australia, p. 126.

Walton J . A. (1970): Woodwork in Theory and Practice, $4^{\text {th }}$ ed., Australian publishing Co., Sydney. P. 204 
1: EXPERIMENTAL RESULTS OF THERMOPHYSICAL PROPERTIES OF DRY M acaranga barteri timber

\begin{tabular}{|c|c|c|c|c|c|c|c|c|c|c|}
\hline $\begin{array}{l}\text { Sample } \\
\text { code }\end{array}$ & $\begin{array}{c}\text { Percentage } \\
\text { moisture } \\
\text { content of fresh } \\
\text { sample } \\
\text { (\%) }\end{array}$ & $\begin{array}{l}\text { Percentage } \\
\text { moisture } \\
\text { content of } \\
\text { season dry } \\
\text { sample } \\
\text { (\%) }\end{array}$ & $\begin{array}{c}\text { Bulk Density of } \\
\text { Dried Sample } \\
\rho_{\mathrm{B}} \\
\left(\mathrm{Kgm}^{-3}\right)\end{array}$ & $\begin{array}{c}\text { Particle Density of } \\
\text { Dried Sample } \\
\rho_{\mathrm{p}} \\
\left(\mathrm{Kgm}^{-3}\right)\end{array}$ & $\begin{array}{l}\text { Thermal } \\
\text { Conductivity of } \\
\text { Dried Sample } \\
\left(\mathrm{Wm}^{-1} \mathrm{~K}^{-1}\right)\end{array}$ & $\begin{array}{c}\text { Thermal } \\
\text { Resistivity of } \\
\text { Dried sample } \\
\left(\mathrm{mKW}^{-1}\right)\end{array}$ & $\begin{array}{c}\text { Percentage } \\
\text { volume of } \\
\text { dead air } \\
\text { space } \\
(\%)\end{array}$ & $\begin{array}{c}\text { Specific Heat } \\
\text { Capacity of Dried } \\
\text { sample } \\
\left(\mathrm{JKg}^{-1} \mathrm{~K}^{-1}\right)\end{array}$ & $\begin{array}{c}\text { Thermal } \\
\text { Diffusivity of } \\
\text { Dried sample } \\
\left(\mathrm{m}^{2} \mathrm{~s}^{-1}\right) \times 10^{-7}\end{array}$ & $\begin{array}{c}\text { Thermal } \\
\text { Absorptivity } \\
\alpha \\
\left(\mathrm{m}^{-1}\right)\end{array}$ \\
\hline AK 01 & 42.019 & 8.09 & $340.78 \pm 15.67$ & $415.31 \pm 23.20$ & $0.0728 \pm 0.0069$ & $13.736 \pm 1.302$ & $17.95 \pm 1.83$ & $1972.91 \pm 21.701$ & $1.0828 \pm 0.1643$ & $18.3262 \pm 1.3906$ \\
\hline AK 02 & 45.550 & 7.35 & $339.89 \pm 15.35$ & $414.15 \pm 23.12$ & $0.0689 \pm 0.0060$ & $14.514 \pm 1.264$ & $17.93 \pm 1.81$ & $1891.773 \pm 19.551$ & $1.0716 \pm 0.1528$ & $18.4222 \pm 1.3133$ \\
\hline AK 03 & 42.472 & 7.72 & $341.06 \pm 15.69$ & $415.27 \pm 23.18$ & $0.0704 \pm 0.0062$ & $14.205 \pm 1.251$ & $17.87 \pm 1.82$ & $1863.618 \pm 19.307$ & $1.1076 \pm 0.1691$ & $18.1198 \pm 1.3830$ \\
\hline AK 04 & 52.572 & 7.06 & $325.92 \pm 14.98$ & $398.48 \pm 22.95$ & $0.0629 \pm 0.0053$ & $15.898 \pm 1.340$ & $18.21 \pm 1.89$ & $2000.114 \pm 21.930$ & $0.9649 \pm 0.1362$ & $19.4135 \pm 1.3705$ \\
\hline AK 05 & 48.586 & 7.33 & $338.00 \pm 15.34$ & $412.09 \pm 23.09$ & $0.0667 \pm 0.0058$ & $14.993 \pm 1.3037$ & $17.98 \pm 1.82$ & $1914.738 \pm 20.981$ & $1.0306 \pm 0.1477$ & $18.7844 \pm 1.3459$ \\
\hline AK MEAN & 46.240 & 7.51 & $337.13 \pm 15.41$ & $411.06 \pm 23.11$ & $0.0683 \pm 0.0060$ & $14.669 \pm 1.292$ & $18.00 \pm 1.83$ & $1928.631 \pm 20.694$ & $1.0515 \pm 0.1540$ & $18.6132 \pm 1.3601$ \\
\hline OK 01 & 50.066 & 7.21 & $337.89 \pm 15.34$ & $412.26 \pm 23.18$ & $0.0635 \pm 0.0056$ & $15.748 \pm 1.389$ & $18.04 \pm 1.84$ & $1863.848 \pm 19.307$ & $1.0083 \pm 0.1451$ & $18.9912 \pm 1.2893$ \\
\hline OK 02 & 47.370 & 7.43 & $341.37 \pm 15.67$ & $416.00 \pm 23.31$ & $0.0671 \pm 0.0058$ & $14.903 \pm 1.288$ & $17.94 \pm 1.83$ & $1907.186 \pm 19.981$ & $1.0306 \pm 0.1472$ & $18.7843 \pm 1.3414$ \\
\hline OK 03 & 44.717 & 7.49 & $338.12 \pm 15.35$ & $411.84 \pm 23.04$ & $0.0690 \pm 0.0060$ & $14.493 \pm 1.260$ & $17.90 \pm 1.81$ & $1886.501 \pm 19.430$ & $1.0817 \pm 0.1543$ & $18.3352 \pm 1.3028$ \\
\hline OK 04 & 41.955 & 7.93 & $340.62 \pm 15.64$ & $413.02 \pm 23.19$ & $0.0719 \pm 0.0068$ & $13.908 \pm 1.315$ & $17.53 \pm 1.79$ & $1922.815 \pm 20.993$ & $1.0978 \pm 0.16622$ & $18.2003 \pm 1.3779$ \\
\hline OK 05 & 40.630 & 8.21 & $351.95 \pm 15.93$ & $425.32 \pm 23.71$ & $0.0752 \pm 0.0071$ & $13.298 \pm 1.255$ & $17.25 \pm 1.74$ & $1898.540 \pm 19.600$ & $1.1234 \pm 0.1688$ & $17.9758 \pm 1.3482$ \\
\hline OK MEAN & 44.948 & 7.65 & $341.99 \pm 15.59$ & $415.69 \pm 23.29$ & $0.0693 \pm 0.0063$ & $14.470 \pm 1.301$ & $17.73 \pm 1.80$ & $1895.778 \pm 19.862$ & $1.0684 \pm 0.1563$ & $18.4574 \pm 1.3319$ \\
\hline AF 01 & 44.021 & 7.59 & $340.13 \pm 15.58$ & $414.89 \pm 23.13$ & $0.0701 \pm 0.0061$ & $14.265 \pm 1.241$ & $17.87 \pm 1.81$ & $1859.934 \pm 17.701$ & $1.1081 \pm 0.1577$ & $18.1158 \pm 1.2893$ \\
\hline AF 02 & 49.146 & 7.16 & $336.32 \pm 15.26$ & $409.96 \pm 23.02$ & $0.0652 \pm 0.0052$ & $15.337 \pm 1.223$ & $18.01 \pm 1.83$ & $1851.84 \pm 18.820$ & $1.0467 \pm 0.1464$ & $18.6381 \pm 1.3037$ \\
\hline AF 03 & 45.443 & 7.34 & $339.22 \pm 15.31$ & $413.28 \pm 23.18$ & $0.0689 \pm 0.0059$ & $14.514 \pm 1.243$ & $17.92 \pm 1.81$ & $1883.706 \pm 19.360$ & $1.0783 \pm 0.1521$ & $18.3647 \pm 1.3144$ \\
\hline AF 04 & 40.164 & 8.36 & $346.04 \pm 15.86$ & $417.07 \pm 23.30$ & $0.0767 \pm 0.0073$ & $13.038 \pm 1.241$ & $17.03 \pm 1.73$ & $1897.294 \pm 19.511$ & $1.1682 \pm 0.1767$ & $17.6433 \pm 1.3346$ \\
\hline AF 05 & 44.340 & 7.58 & $339.98 \pm 15.38$ & $414.05 \pm 23.14$ & $0.0693 \pm 0.0060$ & $14.430 \pm 1.249$ & $17.89 \pm 1.81$ & $1861.019 \pm 19.290$ & $1.0953 \pm 0.1557$ & $18.2238 \pm 1.2956$ \\
\hline AF MEAN & 44.623 & 7.61 & $340.34 \pm 15.48$ & $413.85 \pm 23.15$ & $0.0700 \pm 0.0061$ & $14.317 \pm 1.239$ & $17.74 \pm 1.80$ & $1870.759 \pm 18.936$ & $1.0993 \pm 0.1577$ & $18.1971 \pm 1.3075$ \\
\hline $\begin{array}{l}\text { OVERALL } \\
\text { MEAN }\end{array}$ & 45.270 & $\Sigma=7.59$ & $339.82 \pm 15.49$ & $413.53 \pm 28.18$ & $0.0692 \pm 0.0061$ & $14.485 \pm 1.277$ & $17.82 \pm 1.81$ & $1898.389 \pm 19.831$ & $1.0731 \pm 0.1560$ & $18.4226 \pm 1.3332$ \\
\hline
\end{tabular}

